\title{
Leadership from the Inside Out: Student Leadership Development within Authentic Leadership and Servant Leadership Frameworks
}

\author{
Dr. Christa Kiersch \\ Assistant Professor \\ University of Wisconsin - La Crosse \\ Dr. Janet Peters \\ Assistant Professor \\ Washington State University
}

\begin{abstract}
Developing undergraduate student leaders who are authentic in their leadership and who have a drive to serve and support those around them is not only good for the students and their host schools, but arguably good for students' future employers and even the future of our society. Our goal is to determine how such student leaders could be developed within higher education programs or courses. We take a multi-disciplinary approach and examine the research on leadership development with both student and employee samples, framing the review in authentic and servant leadership theories, integrated with best practices in learning and training. We then build from our review of the literatures to provide concrete recommendations for student leadership development founded in authentic and servant leadership principles and utilizing experiential learning.
\end{abstract}

\section{Background}

Leadership development is a prominent objective in both higher education and business. College and university mission statements commonly reference higher education's efforts to build community and business leaders, and student leadership development is referenced as a primary goal both within and outside of business schools (Smart, Ethington, Riggs, \& Thompson, 2002). Yet, many have critiqued the common approaches to leadership education in business schools, noting they tend to promote inequality and greed (Petriglieri \& Petriglieri Insead, 2015), overemphasize the role of formal power while underemphasizing the role of ethics (Polleys, 2002), and promote a leader-centric perspective (Collinson \& Tourish, 2015).

Developing students' leadership in a way that aligns with the leadership models of business and also prepares them for ethical behavior and decision-making post-graduation would respond to the disheartening findings that business education can make students less ethical (e.g., Dasgupta \& Menon, 201; Drumwright, Prentice, \& Biasucci, 2015) and the lack of connection between student leadership development and the business leadership research (e.g., Klimoski \& Amos, 2012). Thus, the purpose of this review is to provide evidence-based recommendations for student leadership development programs meant to result in more ethical leadership behaviors and decision-making post-graduation.

Both for- and non-profit organizations have long recognized the importance of effective leadership and increasingly emphasize leadership development of employees (Day, Fleenor, 
Atwater, Sturn, \& McKee, 2014). Hence, the research and practice of leadership development provide a unique bridge between the arenas of higher education and business. However, despite the common focus on leadership (and leadership development) from academia and business, there seems to be a ripe opportunity for a stronger connection between the two communities and for a better way of developing students' leadership for post-graduation life.

Improving student leadership programs, especially for undergraduate students, also seems to have a very large 'bang for your buck', because of the early intervention point (most undergraduate students are between 18 and 24; U.S. Department of Education, 2015) and the breadth of stakeholders impacted. For example, we know that student leadership development programs can lead to positive outcomes for higher education institutions, future employers, and of course the students themselves (Cress, Astin, Zimmerman-Oster, \& Burkhardt, 2001; Posner, 2004). If student leadership development could be better linked with ethics and more strongly reflect the cumulative evidence of effective leadership development in organizations (as well as the current needs of organizations and expectations of society), we can expect to see a positive ripple effect within communities.

The field of behavioral ethics (e.g., Ariely, 2012; De Cremer, 2009) posits that ethical/unethical behavior and decision-making are a result of both internal forces (e.g., the leader's intentions and moral character) and external forces (e.g., the norms and social influence of the leader's organization). Thus, to prepare students to have a more positive, ethical impact, student leadership development initiatives should account for both internal and external forces on leadership. Students should build and become more aware of their own values and leadership competencies (i.e., they should develop leadership 'inward'), and students should also become more aware of how external forces and people influence their leadership and vice versa (i.e., they should develop leadership 'outward'). In line with this goal, and in order to provide a common framework for leadership pre- and post-graduation capitalizing on existing research and theory in business leadership, we focus our attention specifically on developing authentic leadership (George, 2000; Luthans \& Avolio, 2003) and servant leadership (Greenleaf, 1977, 1991). Both authentic leadership and servant leadership theories have growing empirical support (e.g., ClappSmith, Vogelsang, \& Avey, 2009; Kiersch \& Byrne, 2015; van Dierendonck \& Nuijten, 2011) for their positive, ethical impact, and leadership development according to these frameworks fits the 'leadership inward and outward' approach required by behavioral ethics principles.

Taken together, authentic and servant leadership provide a framework of positive, ethical, trust-based, and pro-social leadership. Authentic leadership emphasizes self-awareness, acting in accordance with values, balanced and unbiased decision-making and building trust-based relationships (e.g., Ilies, Morgeson, \& Nahrgang, 2005). Servant leadership adds a focus on follower's growth and empowerment, a sense of community stewardship, and further emphasis on ethics, humility and moral behavior (Greenleaf, 1977, 1991; Liden, Wayne, Zhao, \& Henderson, 2008; van Dierendonck \& Nuijten, 2011).

Research has supported servant leadership and authentic leadership as separate and distinct, yet related constructs (e.g., Avolio \& Gardner, 2005) and we have no intention of claiming otherwise. Rather, in examining servant and authentic leadership together, we respond to repeated calls from leadership scholars for increased integration across theories (e.g., Avolio, 
2007; Lord, Brown, Harvey, \& Hall, 2001), echoing the awareness among leadership researchers that there does seem to be some conceptual overlap (e.g., Brown \& Trevino, 2006; Fry, 2003; Owens \& Hekman, 2012). Both represent more inclusive and humanized approaches to leadership and seem useful for guiding student leadership development. We propose an integrated view of the two theories here in the spirit of building bridges not just between higher education and business but also within the field of leadership.

Further supporting the integration of authentic and servant leadership, both theories follow the path of developing leadership 'inward and outward' by combining competencies that are internally focused with competencies that are externally focused. Internally focused competencies include those related to more accurately understanding who one is and what one values, for example the self-awareness dimension of authentic leadership and the humility dimension of servant leadership. Externally focused competencies include those targeting relationships with followers or behaviors that impact other people. Examples of externally focused competencies include authentic behavior in authentic leadership and empowerment in servant leadership. Leadership development framed in authentic and servant leadership theories tends to encourage the development of internally focused competencies first and then progresses to the development of externally focused competencies, thus following the pattern of developing leadership 'inward, then outward.'

We hope that our multi-disciplinary review leads to a better future of leadership, a stronger bridge between student and employee leadership, and increased ethical decision making and behaviors for both students and their future organizations. What follows is a cursory review of the vast literatures on effective leadership development programs (with focus on undergraduate students), leadership development within authentic and servant leadership frameworks, and best practices in pedagogy and training. Building off the work done in these varied disciplines, we then provide specific evidence-based guidelines for ethical student leadership development with authentic and servant leadership principles.

Effective Leadership Development. Research on student leadership development, though not as vast as research on employee leadership development, offers critical insights into common practices and the necessary qualities for effective initiatives. Student leadership development occurs in a variety of formats, including leadership-focused courses, one-time retreats, multi-year programs, and unique experiences (such as study abroad). We attempted to discern some of the 'lessons learned' from this research across the multiple potential formats, as they may apply to authentic and servant leadership development and ultimately the leaders' ethical behaviors and decisions.

Common Practices. Investigations into what is currently done in student leadership development reflects to some extent what is commonplace for organizations, with an added emphasis on some of the more traditional classroom approaches and less emphasis on some of the popular business techniques like coaching, mentoring, and stretch assignments. In a large-scale survey of leadership educators, Jenkins (2013) found that leadership development within a specific course format most frequently utilized discussion-based pedagogies, followed by approaches designed to enhance conceptual knowledge of leadership (e.g., research projects), and personal growth activities (e.g., 
reflective journaling). Techniques that were shown to be relatively less frequently used in leadership classes were skill building activities (e.g., role playing or simulations) and traditional assessments (e.g., exams and quizzes).

Discrete experiences, such as study abroad or leadership retreats, are also commonly used for student leadership development. Leadership workshops or retreats catered to the current leaders of student organizations might happen once a semester or once an academic year. Many schools also utilize external vendors or national leadership experiences, such as LeaderShape (www.leadershape.org) or the Student Leadership Challenge (www.studentleadershipchallenge.com; based off the work of Kouzes and Posner, 2012), to engage select students in leadership development.

Looking across the range of delivery methods and processes of student leadership development, Seemiller and Murray (2013) put forth a model of leadership competencies identified as learning outcomes in a wide range of academic programs. This comprehensive list of 244 competencies (within 61 competency areas, further condensed to eight categories) highlights the prevalence of leadership learning goals (both within and outside of formal leadership development programs) and offers a starting place to understand how leadership is currently defined at higher education institutions. The eight categories, with specific example competencies are: 1) learning and reasoning (problem solving, decision making); 2) self-awareness and development (self-understanding, personal values); 3) interpersonal interaction (healthy relationships, empathy); 4) group dynamics (group development, creating change); 5) civic responsibility (inclusion, community development); 6) communication (listening, conflict negotiation); 7) strategic planning (vision, mission); 8) personal behavior (ethics, confidence). These competency categories describe what the current values of 'good leadership' are in higher education, but do not provide direction regarding what these values should be. The breadth and inclusivity of the competency model is also somewhat of a double-edged sword when it comes to developing concrete leadership development programs. While all institutions and current programs could identify with the competencies listed, such a big list does little to provide direction or specific recommendations. Without a more specific model of student leadership development based in broader leadership theory and research, there exists no concrete guide for business schools and universities to provide the kind of leadership development for students to positive contribute in organizations and society post-graduation.

Qualities for Effectiveness. In a direct attempt to determine what makes a 'highquality' student leadership development program, Eich (2008) took an in-depth look at four successful undergraduate leadership programs in the United States. Common elements across these successful programs included: engaged and diverse students working intimately with experienced and modeling educators, experiential and practicebased learning, a supportive culture and match with priorities of the school, and continuous program improvement. Grunwell (2015) found similar themes for effective student leadership in a case study of one successful retreat-style program, again highlighting the importance of practice-based and self-directed learning, a supportive environment, and ongoing development. Further, Allen and Hartman (2009) found that students preferred many of the same qualities that Eich (2008) and Grunwell (2015) 
concluded were necessary for program effectiveness, including a focus on personal growth and skill building.

Perhaps not surprisingly, many of the same characteristics for success have been highlighted in the leadership development research with non-student populations, though the process often differs. In a recent review of leadership development research in organizations, Day and colleagues (2014) mirror much of the student leadership research and acknowledge the criticality of developing greater self-awareness, having positive mentors, and actively engaging in leadership behaviors to become a better leader. A noticeable difference between student and employee programs comes in how developing leaders achieve these outcomes. Evidence-based recommendations specific to business environments include using 360-feedback to develop greater self-awareness, executive coaching to provide mentorship, and thoughtful stretch assignments to practice leadership behaviors.

Additional research from the business community highlights the broader context necessary for effective leadership development, again echoing the need for a supportive community and ongoing development in student leadership programs. Barling, Weber, and Kelloway (1996) found that simply offering 'booster sessions' after a discrete leadership experience (e.g., a workshop or retreat) provided some avenue for ongoing development and support and increased the effectiveness of the program. Further, in a review of best practices in organizational leadership development, Leskiw and Singh (2007) emphasized the importance of the support and context of the leaders' environment for positive and lasting leadership growth.

Although the environment and resources available will differ between most businesses and most higher education institutions, the impact of these contextual variables on the success of leadership development programs remains constant. Similarly, the research in both academic and business communities has emphasized active or experiential learning, mentors or positive models, and increased self-awareness as keys to success. It is clear that many of the same principles for effective leadership development hold regardless of the target population (students or employees) yet the research on each group remains siloed. We believe that one reason for such a separation is the lack of common language and common theoretical framework for effective leadership. In the interest of breaking down the silos and connecting student leadership development with the broader leadership research, while emphasizing the behavioral ethics principles as applied to leadership, we propose a combination of authentic and servant leadership as such a connecting bridge.

Authentic and Servant Leadership as a Connecting Framework. Authentic leadership theory and servant leadership theory offer two complementary frameworks (or, when combined, one more complex framework) for developing effective and ethical leaders in higher education and business contexts. Principles from these theories have been successfully used to develop student leadership (e.g., Eriksen, 2009; Polleys, 2002) and leadership in for- and nonprofit organizations (e.g., Day et al., 2014). Each theory has been well-developed and supported within the literature, providing a strong foundation for evidence-based practice. 
Justification for the Servant/Authentic Leadership Framework. We argue that the time has come to strengthen the connection between the broad base of leadership research and student leadership development, and to more intentionally infuse behavioral ethics into student leadership development. Authentic and servant leadership theories compliment the principles of behavioral ethics, emphasizing integrity and ethical decision-making as key tenants of effective leadership while acknowledging both internal and external influences on both leadership and ethical behavior. Both theories are used in the leadership and leadership development literatures with employee populations, allowing them to 'bridge' students' leadership development pre- and post-graduation. Finally, there is growing evidence that both students and employees can grow as authentic and servant leaders, indicating the utility of these frameworks for guiding student leadership development (and not just for describing what effective and/or ethical leadership means).

Higher education, business leaders, and members of society alike have called for leaders who are honest, engaged in pro-social change, and able to make a difference. The Kellogg Foundation issued a call to action for higher education to take on the responsibility for developing future leaders capable of bringing a diverse society together towards collaborative solutions to current social problems (Astin et al., 2000).

Organizational stakeholders are recognizing the power of servant and authentic leadership, perhaps partly due to growing empirical support for positive outcomes ranging from increased helping behaviors to employee burnout and turnover (Hirst, Walumbwa, Aryee, Butarbutar, \& Chen, 2015; Spence Lashinger \& Fida, 2014). Finally, in an age of corporate corruption and scandal, the general public seems fed up with the previous status-quo and more than ready for a new kind of ethical and collaborative leader (e.g., Walumbwa et al., 2008).

This new kind of leader is in stark contrast to how undergraduate students commonly think of leadership, wherein leadership tends to be conceptualized as individualistic and trait-focused (e.g., Haber, 2012; Schertzer \& Schuh, 2004). That is, students tend to focus on the formal power aspects of leadership (authority, influence, decision making) and underestimate the importance of the relational aspect (support, collaboration, development of followers, etc.). The discrepancy between the leadership needs of modern organizations and students' traditional understanding of leadership creates a mismatch that needs to be resolved (Rosch \& Caza, 2012). Undergraduate leadership development programs founded in authentic and servant leadership principles can align the desires of future employers, the expectations of society, and the knowledge, skills, and abilities of current students. Such programs can help students understand the role of the leader within the broader context of the organization, not just as a figure head or someone who exerts power and influence over others. Developing student leaders in line with servant and authentic leadership principles has the potential to change the future 'norms' of leadership for the better.

Key principles from authentic and servant leadership are apparent in the research on effective student leadership development programs, providing further support for 
these theories as connecting frameworks. Although the specific terms "authentic leadership" or "servant leadership" may not always be used, the focal leadership skills or characteristics often align well with these theories. For example, Eich (2008) found that effective programs help students develop through self-discovery (a heavy theme in authentic leadership development) and involve engagement in service learning, concluding that "High-quality programs actually practice the kind of inclusive, empowering, purposeful, ethical, and process-oriented leadership for positive change that they advocate to their students" (p. 186), again showing the weight given to ethical behavior and pro-social impact apparent in servant leadership.

\section{Summary of Authentic and Servant Leadership Theories}

Authentic Leadership. Authentic leadership theory posits that effective leadership is all about being honest, real and authentic with all stakeholders (Avolio \& Gardner, 2005; George, 2003; Luthans \& Avolio, 2003). To engage in authentic leadership, one must be self-aware and in touch with one's priorities and values (what we call the inward-focused component of authentic leadership), and also be transparent in action and encourage open sharing of information and positive relationships (what we call the outward-focused component of authentic leadership). As a leadership theory and framework for leadership development, authentic leadership has both gained popularity in the business community (propelled largely by George, 2003) and gained empirical support (e.g., Clapp-Smith, Vogelsang, \& Avey, 2009; Kiersch \& Byrne, 2015). Building off the foundational work of George (2003), and Luthans and Avolio (2003), Ilies, Morgeson, and Nahrgang (2005) provide a four-dimensional model of authentic leadership that may be useful in building a leadership development program founded in this theory: 1) self-awareness, the awareness and trust of one's own personal values, motives, feelings, and cognitions; 2) unbiased processing, including all relevant knowledge and experience in decision-making without denying, distorting, or exaggerating the evidence; 3 ) authentic behavior, acting in accord with one's true self rather than acting to please others or for the purpose of obtaining rewards or avoiding punishment; 4) authentic relational orientation, one's active process of self-disclosure and the development of trust-based relationships. These four dimensions are captured in the validated and non-proprietary measure of authentic leadership, the Authentic Leadership Inventory (ALI; Neider \& Schriesheim, 2011). Thus, the four-dimensional model could be used as a framework to guide authentic student leadership development and the ALI could be used in ongoing program evaluation and improvement.

Servant Leadership. The basis of servant leadership theory is for leaders to act as servants to their followers or team (Greenleaf, 1977). Within this framework, effective leaders are humble yet courageous (what we call the inward-focused components of servant leadership). They emphasize follower empowerment and development, exhibit strong ethical and moral behavior, and put the 'greater good' above their own self-interest (what we call the outward-focused components of servant leadership; e.g., Greenleaf, 1977. 1991; van Dierendonck \& Nuijten, 2011). According to van Dierendonck and Nuijten (2011) servant leadership is comprised of eight key characteristics, which can be measured by their Servant Leadership Survey: 1) empowerment, believing in others and 
enabling others' development; 2) accountability, developing clear goals then holding others accountable for achieving set standards; 3 ) standing back, giving others credit and support; 4) humility, awareness of limitations and acceptance of any mistakes; 5) authenticity, presenting one's 'true' self; 6) courage, daring to take risks and challenge conventional practices; 7) interpersonal acceptance, empathy and understanding; and 8) stewardship, focusing on the common good above self-interest.

Combining the two models of authentic leadership competencies and servant leadership competencies results in 11 competencies that may frame leadership development (notably, there are 11 competencies instead of 12 due to the full conceptual overlap of 'authenticity' in servant leadership with 'authentic behavior' in authentic leadership.) Following the pattern of 'inward-and-outward' leadership development from these two frameworks, the competencies are listed according to 'internal focus' or 'external focus', along with brief definitions, in Table 1. 
Table 1. Authentic and Servant Leadership Competency Model

\begin{tabular}{|c|c|c|}
\hline \multicolumn{2}{|c|}{ Leadership Competencies } & \multirow[t]{2}{*}{ Definition/explanation } \\
\hline \multicolumn{2}{|c|}{$\begin{array}{l}\text { 'Inward' } \\
\text { Focused }\end{array}$} & \\
\hline & Self-awareness (AL) & $\begin{array}{l}\text { Understanding one's own personal values, } \\
\text { motives, feelings, and cognitions }\end{array}$ \\
\hline & Unbiased processing (AL) & $\begin{array}{l}\text { Including all relevant knowledge and } \\
\text { experience in decision-making without } \\
\text { denying or distorting evidence }\end{array}$ \\
\hline & Humility (SL) & $\begin{array}{l}\text { Knowing one's limitations; acceptance of } \\
\text { mistakes made }\end{array}$ \\
\hline & Courage (SL) & $\begin{array}{l}\text { Daring to take risks; challenging conventional } \\
\text { models or wisdom }\end{array}$ \\
\hline \multicolumn{3}{|l|}{$\begin{array}{l}\text { 'Outward' } \\
\text { Focused }\end{array}$} \\
\hline & $\begin{array}{l}\text { Authentic behavior (AL)/ } \\
\text { Authenticity (SL) }\end{array}$ & $\begin{array}{l}\text { Presenting one's authentic self; acting in } \\
\text { accordance with personal values }\end{array}$ \\
\hline & $\begin{array}{l}\text { Authentic relational orientation } \\
\text { (AL) }\end{array}$ & $\begin{array}{l}\text { Active process of self-disclosure and } \\
\text { development of trust-based relationships }\end{array}$ \\
\hline & Empowerment (SL) & $\begin{array}{l}\text { Enabling and encouraging others' } \\
\text { development; believing in the value of each } \\
\text { individual }\end{array}$ \\
\hline & Accountability (SL) & $\begin{array}{l}\text { Setting clear expectations; having confidence } \\
\text { in others; holding others accountable for } \\
\text { controllable behavior and outcomes }\end{array}$ \\
\hline & Standing Back (SL) & $\begin{array}{l}\text { Giving priority to others' interests; giving } \\
\text { others support and credit }\end{array}$ \\
\hline & Interpersonal acceptance (SL) & $\begin{array}{l}\text { Empathy; understanding where people come } \\
\text { from }\end{array}$ \\
\hline & Stewardship (SL) & $\begin{array}{l}\text { Focus on the common good above self- } \\
\text { interest; acting as a role model }\end{array}$ \\
\hline
\end{tabular}

*Note: AL = Authentic Leadership; SL = Servant Leadership

Application of the Integrated Framework to Student Leadership Development. For guidance on how the principles of servant and authentic leadership can be put into practice in student leadership development, we look to existing research in organizations and case studies in higher education. These bodies of research illustrate the utility of both servant and authentic leadership theories as frameworks for leadership development and provide an important foundation for our proposed recommendations regarding student leadership development. Often leadership development tools or methods are most effective in targeting specific dimensions of authentic or servant leadership (rather than the whole framework); later, we will seek to integrate across tools and methods to inform a more complete authentic and servant leadership development program. 
Within organization settings, coaching has been supported as a tool for leadership development generally, and authentic leadership development specifically. Kinsler (2014) proposes a combination of leadership coaching and mindfulness training for building greater self-awareness and relational transparency at the heart of authentic leadership. Ladegard and Gjerde (2014) provide an assessment of leadership development programs based in leadership coaching, with results supporting the effectiveness of coaching for increased leader role-efficacy and leader's trust in followers (thought to be pre-cursor to follower empowerment). Assessment data also suggested specific recommendations for enhancing the effectiveness of coaching, namely to maximize the degree of facilitative behavior from the coach.

Leadership development research based in the broader framework of positive organizational studies (POS) may also be well suited to inform authentic and servant leadership development. Spreitzer (2006) provides a guide to leadership development based in POS and aligning with a classic three-step approach to development put forth by the Center for Creative Leadership (McCauley \& Van Velsor, 2003). Step 1 entails an assessment of one's current leadership, emphasizing one's leadership strengths. Step 2 involves providing 'positive jolts' to stimulate growth and leverage one's strengths (e.g.., sharing appreciation for what the leader has done may be a 'positive jolt' for the leader to build upon the noticed strengths). Step 3 ensures the longevity and continuous nature of leadership development by focusing on the co-creation of support and resources for ongoing growth. Within this recommended three-step model, specific components seem to align directly with dimensions of authentic and/or servant leadership. For example, a recommended tool to assess one's current leadership strengths and provide a 'positive jolt' for growth is the Reflected Best Self (RBS) assessment (McCauley \& Van Velsor, 2003). This tool requires leaders to obtain strength-oriented feedback from a diverse group of people connected with them (professionally and personally), then to integrate the feedback to compose a portrait of their 'best self'. This exercise has been used successfully within organizations and with both graduate and undergraduate students, resulting in heightened self-awareness and authenticity as well as stronger social relationships and motivation for strength-based growth (Spreitzer, 2006). While the use of the Reflected Best Self assessment aligns most closely with dimensions of authentic leadership, strategies for Step 3 of the process (co-creation of resources to support ongoing growth) more directly apply to developing servant leadership. Specifically, Spreitzer (2006) argues for leaders to create an integrated common knowledge base within organizations so that any organizational members (i.e., 'followers') can be empowered to solve any problems that arise. Facilitating this kind of open information sharing shifts power from the traditional hierarchical model (giving power to the 'leader' on top) to a more equal sharing of power among all organizational members, aligning with the core principles of servant leadership and specifically the empowerment and standing back dimensions.

There are also many notable published examples of student leadership development programs highlighting one or more specific dimensions of servant or authentic leadership. For example, some schools are using service learning projects embedded in various courses to emphasize the importance of community service and the servant leadership principle of putting the greater good above one's self interest (e.g., Snell, Chan, Ma, \& Chan, 2015). Others are utilizing a campus-wide leadership initiative that embraces the servant leadership philosophy through incorporation of extensive community service and mentoring. Polleys (2002) provides an overview of one such initiative at Columbus State University. Within this campus-wide 
program, students develop as servant leaders via a combination of classroom-based learning, community service, and mentoring, all guided by the servant leadership philosophy.

Across program formats, community service seems to be an essential common thread of all published examples of student servant leadership development. Any form of community service will likely influence students' stewardship (one of the characteristics of servant leadership), and thoughtful additions to community service experiences have the potential for influencing other characteristics of servant leadership as well. Adding a team, project-based dimension to community service (like that recommended by Snell et al., 2015) allows students to develop project management and relationship management skills/behaviors, and could help students to increase in accountability and empowerment. Community service that puts students 'outside of their comfort zone' could aid in developing interpersonal acceptance, and even humility and courage.

Authentic leadership principles are also emerging in the leadership education literature. Two components of authentic leadership that seems to be getting a large share of the attention are self-awareness (regarding one's own strengths and weaknesses as well as values and morals) and unbiased processing (taking all relevant information into account and limiting, to the extent possible, the influence of bias). Taken together, these aspects of authentic leadership focus students' attention inward, and the research in this area tends to present specific exercises to help guide internal exploration. For example, Branson (2007) found that structured self-reflection helped to increase students' self-knowledge of their personal values. Similarly, Eriksen (2009) illustrates the power of self-narratives (both developing them and sharing them out loud) in developing greater awareness of students' own values and beliefs and also acceptance of the values and beliefs of others. The self-narrative assignment, adapted from the international project This I Believe (http://thisibelieve.org), first guides student self-reflection through set prompts encouraging thoughtful identification of personal values (specifically related to leadership and more general) and also recognition of how personal values impact one's leadership behaviors and relationships with others. This guided self-reflection process results in a written selfnarrative that is then read aloud (or recorded) and shared with other students. The sharing of narratives not only provides greater ownership of the self-narratives for the authors sharing them, but also encourages open-mindedness and empathy for those on the receiving end.

As we have described, most of the research on student authentic leadership development takes one specific component of authentic leadership and examines or illustrates a method for developing that component in students. Exceptions to this research template include Berkovich's (2014) empirically-based call for a dialogical pedagogy approach to authentic leadership development in students. Berkovich reminds us that authentic leadership is not just about looking inward and becoming aware of and confident in one's true self but also about looking outward and building authentic relationships with others. Dialogical pedagogy involves including others, being actively present with others, and having open communication with candor. Applied to student leadership development, dialogical pedagogy provides more of a general framework for authentic leadership growth than specific exercises. However, any exercises that helped students to strengthen such outward focused skills as open communication would fit this approach and likely make positive additions to the authentic/servant leadership development program. 
Integrating Best Practices in Pedagogy and Training. As Day and colleagues (2013) point out, effective leadership development requires more than an understanding of effective leadership - it also requires an understanding of effective development more broadly. For this, we turn to the experts on such targeted human development (i.e., education, learning, and training). We specifically focus on the experiential learning literature for relevant, evidencebased recommendations that may be applied to student leadership development.

Experiential Learning Theory (ELT). "Knowledge is a necessary first step, but by itself it is not sufficient for changing leadership behavior. The new knowledge must be put into action. Skills encompass the action domain of learning," (McDonald-Mann, 1998, p. 107).

Scholars and managers have long recognized the importance of diverse approaches to learning about leadership. In perusing the pedagogical literature (both within management education and outside of it), one can see the many theories, models, and approaches offered to anyone interested in leadership development. One of the most influential approaches to management teaching and learning is Kolb's (1984) work based on experiential learning. Experiential Learning Theory (ELT) is based on an integrative framework from a variety of theoretical orientations, including John Dewey, Kurt Lewin, Jean Piaget, William James, Carl Jung, and Carl Rogers (Kolb, 1984; Kolb \& Kolb, 2012). Though designed to be a holistic approach to learning, one of its most popular applications has been in management education. According to ELT, individuals learn by resolving a set of competing learning tensions, which results in the individual engaging in a dialectic, cyclical process that leads to new knowledge and skills.

The four components of ELT. Experiential Learning Theory is a learning process based upon the progression through four types of learning: concrete experiences, reflective observation, abstract conceptualization, and/or active experimentation (Kolb, 1984). Concrete experience involves the "tangible, felt qualities of the world, relying on our senses and immersing ourselves in concrete reality" (Kolb, Boyatzis, \& Mainemelis, 2000, p. 3). Reflective observation occurs when the learner thinks about previous observations and experiences; they spend time observing and considering what worked and what failed to work. Third, abstract conceptualization refers to the analytical knowledge, analysis, and thinking about a specific problem. Finally, active experimentation involves learning by doing, in which the learner actively engages in the activity.

According to Kolb and Kolb (2012), these four components work together to create a cyclical learning experience, wherein learners use their immediate experiences (concrete experiences) to form observations and reflections about the content (reflective observation). In turn, their observations and reflections help them to form new hypotheses and implications (abstract conceptualization) that can be tested once they are given the opportunity to apply the information (active experimentation). As the learner gains new experiences and assimilates new information, the process repeats itself. Thus, the basic progression proposed by ELT suggests that the process "...is portrayed as an idealized learning cycle or spiral where the learner 'touches all the bases' - experiencing, reflecting, thinking, and acting - in a recursive process that is responsive to the learning situation and what is being learned" (Kolb \& Kolb, 2012, p. 44). 
ELT in business and leadership education. Although ELT has received some criticism (e.g., Freedman \& Stumpf, 1980), the basic tenets of the learning process (reflection, experiential opportunities, abstract conceptualization, and active experimentation) have been widely accepted and utilized by the educational and management literature (e.g., Blackwell, Cummmins, Townsend, \& Cummings, 2007; Garvin, 2007; Godfrey, Ilies, \& Berry, 2005). As Lidon, Rebollar, and Moller (2011) point out, there is an increasing need for applied sciences to support theory and knowledge with practice and application. Some scholars have gone so far as to claim that for a business education program to be considered a quality program, it must include an experiential learning component (Clark \& White, 2010). Thus, the need for experiential learning programs has created a challenge and opportunity for business education programs (Lidon et al., 2011), particularly in regards to leadership development. To meet this demand, some programs have created individualized leadership learning experiences. For example, Blackwell et al. (2007) utilized ELT in their leadership development program, where each aspect of ELT was achieved through a semester long research project (e.g., abstract conceptualization was achieved through lectures; active experimentation through the development of problem statements; concrete experience through data collection and evaluation; reflective observation through evaluation of the process). In a more experiential based approach, Clark and White (2010) discuss the use of ELT in their "Walgreens Wrangle," a multi-university business strategy competition.

While these applications of ELT into leadership development programs are an excellent start and worthwhile endeavor, most of the work being done is specific to each individual institution. Therefore, we seek to address this shortcoming by providing ELT-based guidelines that focus on authentic and servant leadership for student leadership development that can be applied to any program. That is, leadership development programs should be designed to help students develop the knowledge and competencies to move beyond classroom application and into their future professional and civic settings.

\section{Recommendations for Student Authentic and Servant Leadership Development}

Building on the literatures in authentic and servant leadership development, referring to the principles of behavioral ethics, and highlighting the four facets of ELT, we propose four general evidence-based guidelines for successful student leadership development programs. We then present a model of the target competencies of an authentic/servant leadership development program for students, along with examples of exercises and specific program components to target each competency. Taken together, the following guidelines and competency model, along with the associated example developmental exercises and experiences, are intended to serve as the basis for developing student leaders who are ethical in behavior and decision-making, selfaware, honest, and driven to serve others.

ELT-based Guidelines. The four facets of ELT translate into four principles for any student leadership development program. We argue these principles be used in guiding the development of any program, initiative, or assignment designed to develop students' authentic and servant leadership. Rather than specifying leadership-specific content, these principles are intended to guide the process and delivery of the leadership development experience. 
1. Heavy emphasis should be placed on hands-on activities and simulations as primary tools of student leadership development, especially in early stages of such development (ELT facet: concrete experience).

2. Leadership 'experiences' (including in-class activities) and students' ongoing leadership development journey should incorporate purposeful reflection to aid growth and selfawareness (ELT facet: reflective observation).

3. Conceptual framework should be provided for hands-on learning utilizing a range of delivery media (e.g., lecture, text, video) and sources (e.g., instructors, guest lecturers, community leaders), allowing students to build knowledge of servant and authentic leadership and see themselves as authentic/servant leaders (ELT facet: abstract conceptualization).

4. Students should be given the opportunity for out of class, service learning experiences that allow them to practice and apply their developing leadership in a way that benefits some greater good (ELT facet: active experimentation).

Target Competencies \& Sample Program Components. Based on the established eight dimensions of servant leadership (van Dierendonck and Nuijten, 2011) and the four dimensions of authentic leadership (Iles, Morgeson, and Nahrgang (2005), we have proposed a model of 11 target leadership competencies for an authentic/servant student leadership development program (see Table 1). Growth in each of the target competencies represents a concrete set of learning outcomes, the goals for an authentic/servant student leadership development program. To achieve these learning outcomes, we integrate the reviewed research on effective leadership development and incorporate principles of ELT to provide specific recommendations. In Table 2, we offer concrete exercises or program components with additional sources for further details and, when possible, supporting evidence for effectively impacting the associated competency. Because many program components target multiple competencies at once, they are organized by competency area (internally or externally focused) rather than by specific competency. Further research assessing the effectiveness of any student leadership development program informed by our recommendations is needed to more precisely estimate the impact of any particular exercise on any particular competency. 
Table 2. Authentic and Servant Leadership Development Program Components

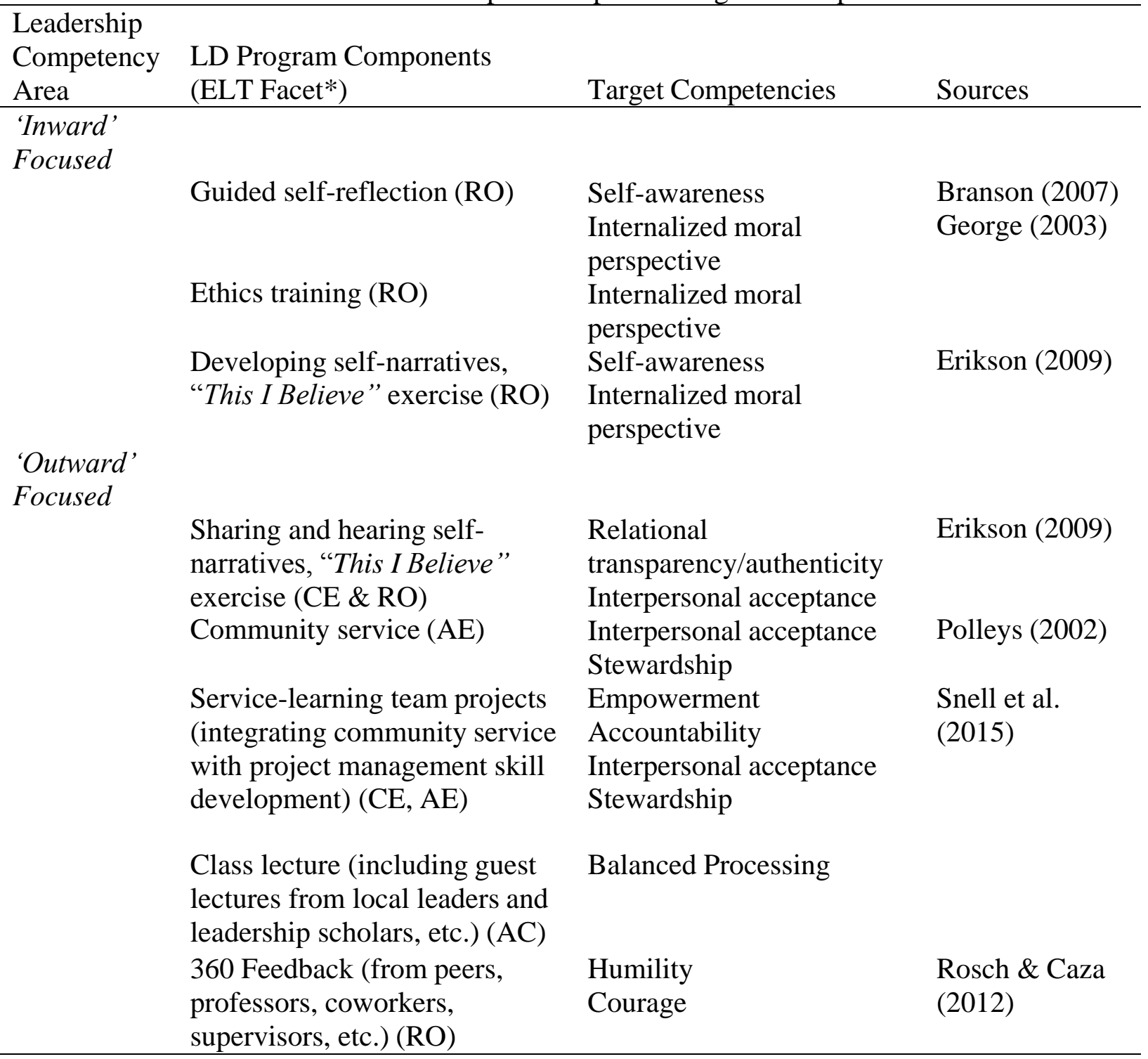

*Concrete Experience (CE), Reflective Observation (RO), Abstract Conceptualization (AC), Active Experimentation (AE)

All of the authentic/servant leadership competencies can be assessed by validated survey measures, allowing any leadership development program based in this proposed framework to be evaluated. To evaluate the competencies associated with servant leadership, we refer to the Servant Leadership Survey (van Dierendonck \& Nuijten, 2011). Authentic leadership competencies can be assessed via the the Authentic Leadership Inventory (ALI; Neider \& Schriesheim, 2011).

Although each of our recommendations is based on current evidence, ongoing research should be done to test the effectiveness of any combination of recommendations and of the proposed authentic/servant student leadership development program as a whole. This continuous 
process of testing and evaluating any student authentic/servant leadership development program follows the established best practices of leadership development programs in organizations (Leskiw \& Singh, 2007) and would serve to fuel a positive dialogue in student leadership development moving forward.

\section{Conclusion}

Student leadership development weighs heavily on the minds of universities, faculty, and future employers. Now, more than ever, we are seeing the call for leaders that are ethical, transparent, and trustworthy. To meet these demands, we propose that student leadership development initiatives turn leadership 'inside-out' as a way to help promote ethical behaviors and decision-making among our future leaders. To support the inward and outward development of ethical leaders, we have suggested that leadership development programs address eleven main competencies (self-awareness, unbiased processing, humility, courage, authentic behavior/authenticity, authentic relational orientation, empowerment, accountability, standing back, interpersonal acceptance, and stewardship) through the use of experiential learning. By creating a robust education that involves action, reflection, cognition, and experience, students can be more fully prepared to lead in world with complex moral issues and competing demands for time, energy, and organizational resources.

\section{References}

Allen, S. J., \& Hartman, N. S. (2009). Sources of learning in student leadership development programming. Journal of Leadership Studies, 3, p. 6-16.

Ariely, D. (2012). The (honest) truth about dishonesty. New York: HarperCollins.

Astin, A. W., Astin, H. S., Allen, K. E., Burkhardt, J. C., Cress, C. M., Flores, R. A., Jones, P., Lucas, N. J., Pribush, B. L., Reckmeyer, W. C., Parker Smith, B., Zimmerman-Oster, K. A. (2000). Leadership reconsidered: Engaging higher education in social change. W. K. Kellogg Foundation, p.1-103.

Avolio, B. J. (2007). Promoting more integrative strategies for leadership theory-building. American Psychologist, 62, p. 25-33.

Avolio, B. J., \& Gardner, W. L. (2005). Authentic leadership development: Getting to the root of positive forms of leadership. Leadership Quarterly, 16, p. 315-338.

Barling, J., Weber, T., \& Kelloway, E. K. (1996). Effects of transformational leadership training on attitudinal and financial outcomes: A field experiment. Journal of Applied Psychology, 81, p. 827 - 832.

Berkovich, I. (2014). Between Person and Person: Dialogical Pedagogy in Authentic Leadership Development. Academy Of Management Learning \& Education, 13, p. 245-264. 
Blackwell, C., Cummins, R., Townsend, C. D., \& Cummings, S. (2007). Assessing perceived student leadership skill development in an academic leadership development program. Journal of Leadership Education, 6, p. 39-58.

Branson, C. (2007). Effects of Structured Self-reflection on the Development of Authentic Leadership Practices among Queensland Primary School Principals. Educational Management Administration \& Leadership, 35, p. 225-246.

Brown, M. E., \& Treviño, L. K. (2006). Ethical leadership: A review and future directions. Leadership Quarterly, 17, p. 595-616.

Clapp-Smith, R., Vogelgesang, G. R., \& Avey, J. B. (2009). Authentic leadership and positive psychological capital: The mediating role of trust at the group level of analysis. Journal of Leadership \& Organizational Studies, 15, p. 227-240.

Clark, J., \& White, G. W. (2010). Experiential learning: A definitive edge in the job market. American Journal of Business Education, 3, p. 115-118.

Collinson, D., \& Tourish, D. (2015). Teaching leadership critically: New directions for leadership pedagogy. Academy Of Management Learning \& Education, 14, p. 576-594.

Cress, C. M., Astin, H. S., Zimmerman-Oster, K., \& Burkhardt, J. C. (2001). Developmental outcomes of college students' involvement in leadership activities. Journal of College Student Development, 42, p. 15-27.

Dasgupta, U., \& Menon, A. (2011). Trust and trustworthiness among economics majors. Economic Bulletin, 31(4), p. 2799-2815.

Day, D. V., Fleenor, J. W., Atwater, L. E., Sturm, R. E., \& McKee, R. A. (2014). Advances in leader and leadership development: A review of 25 years of research and theory. Leadership Quarterly, 25, p. 63-82.

De Cremer, D. (2009). Psychological perspectives on ethical behavior and decision making, Information Age Publishing.

Drumwright, M., Prentice, R., \& Biasucci, C. (2015). Behavioral ethics and teaching ethical decision making. Decision Sciences Journal of Innovative Education, 13(3), p. 431-458.

Eich, D. (2008). A grounded theory of high-quality leadership programs: Perspectives from student leadership development programs in higher education. Journal of Leadership \& Organizational Studies, 15, p. 176-187

Eriksen, M. (2009). Authentic Leadership. Journal of Management Education, 33, p. 747-771.

Freedman, R. D., \& Stumpf, S. A. (1980). Learning style theory: Less than meets the eye. Academy of Management Review, 5, p. 445-447. 
Fry, L. W. (2003). Toward a theory of spiritual leadership. Leadership Quarterly, 14, p. 693-727.

George, B. (2003). Authentic leadership: Rediscovering the secrets to creating lasting value. San Francisco, CA: Jossey-Bass.

Godfrey, P. C., Ilies, L. M., \& Berry, G. R. (2005). Creating breadth in business education through service-learning. Academy of Management Learning \& Education, 4, p. 309-323.

Greenleaf, R. K. (1977). Servant-leadership: A journey into the nature of legitimate power and greatness. New York: Paulist Press.

Greenleaf, R. K. (1991). The servant as leader. Indianapolis: The Greenleaf Center.

Grunwell, S. G. (2015). Leading our world forward: An examination of student leadership development. Journal of Leadership Education, 14, p. 82-99.

Haber, P. (2012). Perceptions of leadership: An examination of college students' understandings of the concept of leadership. Journal of Leadership Education, 11, p. 26-51.

Hirst, G., Walumbwa, F., Aryee, S., Butarbutar, I., Chen, C. J. H. (2015). A multi-level investigation of authentic leadership as an antecedent of helping behavior. Journal of Business Ethics, 126, p. 1-15.

Ilies, R., Morgeson, F. P., \& Nahrgang, J. D. (2005). Authentic leadership and eudemonic wellbeing: Understanding leader-follower outcomes. The Leadership Quarterly, 16, p. 373394.

Jenkins, D. M. (2013). Exploring instructional strategies in student leadership development programming. Journal of Leadership Studies, 6, p. 48-62.

Kiersch, C. E., Byrne, Z. S. (2015). Is being authentic being fair? Multilevel examination of authentic leadership, justice, and employee outcomes. Journal of Leadership \& Organizational Studies, 22, p. 1-12.

Kinsler, L. (2014). Born to be me... who am I again? The development of Authentic Leadership using Evidence-Based Leadership Coaching and Mindfulness. International Coaching Psychology Review, 9, p. 92-105.

Klimoski, R., \& Amos, B. (2012). Practicing evidence-based education in leadership development. Academy of Management Learning \& Education, 11, p. 685-702.

Kolb, D. A. (1984). Experiential learning: Experience as the source of learning and development. Englewood Cliffs, NJ: Prentice-Hall. 
Kolb, A. Y., \& Kolb, D. A. (2012). Experiential learning theory. In Encyclopedia of the Sciences of Learning (pp. 1215-1219). Springer US.

Kolb, D. A., Boyatzis, R. E., \& Mainemelis, C. (2001). Experiential learning theory: Previous research and new directions. Perspectives on Thinking, Learning, And Cognitive Styles, 1 , p. 227-247.

Kouzes, J. M., \& Posner, B. Z., (2012). The leadership challenge: How to make extraordinary things happen in organizations (5th ed.). Hoboken, NJ: John Wiley \& Sons.

Ladegard, G., \& Gjerde, S. (2014). Leadership coaching, leader role-efficacy, and trust in subordinates. A mixed methods study assessing leadership coaching as a leadership development tool. Leadership Quarterly, 25, p. 631-646.

Leskiw, S., \& Singh, P. (2007). Leadership development: Learning from best practices. Leadership and Organizational Development Journal, 28, p. 444-464.

Liden, R. C., Wayne, S. J., Zhao, H., \& Henderson, D. (2008). Servant leadership: Development of a multidimensional measure and multi-level assessment. The Leadership Quarterly, 19, p. 161-177.

Lidón, I., Rebollar, R., \& Møller, C. (2011). A collaborative learning environment for management education based on experiential learning. Innovations in Education and Teaching International, 48, p. 301-312.

Lord, R. G., Brown, D. J., Harvey, J. L., \& Hall, R. J. (2001). Contextual constraints on prototype generation and their multilevel consequences for leadership perceptions. The Leadership Quarterly, 12, p. 311-338.

Luthans, F., \& Avolio, B. J. (2003). Authentic leadership development. In K. S. Cameron, J. E. Dutton, \& R. E. Quinn (Eds.), Positive organizational scholarship (pp. 241-258). San Francisco: Berrett-Koehler.

McCauley, C., \& Van Velsor, E. (2003). The Center for Creative Leadership handbook of leadership development. San Francisco, CA: Jossey-Bass.

McDonald-Mann, D. G. (1998). Skill-based training. In McCauley, C. D., Moxley, R. S., \& Van Velsor, E. (Eds.). The Center for Creative Leadership handbook of leadership development (pp. 106-126). San Francisco: Jossey-Bass.

Neider, L. L., \& Schriesheim, C. A. (2011). The authentic leadership inventory (ALI): Development and empirical tests. The Leadership Quarterly, 22(6), p. 1146-1164.

Owens, B. P., \& Hekman, D. R. (2012). Modeling how to grow: An inductive examination of humble leader behaviors, contingencies, and outcomes. Academy of Management Journal, 55, p. 787-818. 
Petriglieri, G., \& Petriglieri Insead, J. L. (2015). Can business schools humanize leadership? Academy Of Management Learning \& Education, 1, p. 625-647.

Polleys, M. S. (2002). One university's response to the anti-leadership vaccine: Developing servant leaders. Journal of Leadership Studies, 8, p. 117-130.

Posner, B. Z. (2004). A leadership development instrument for students: Updated. Journal of College Student Development, 45, p. 443-456.

Rosch, D. M., \& Caza, A. (2012). The durable effects of short-term programs on student leadership development. Journal of Leadership Education, 11, p. 28-48.

Seemiller, C., \& Murray, T. (2013). The common language of leadership. Journal of Leadership Studies, 7, p. 33-45.

Schertzer, J. E. \& Schuh (2004). College student perceptions of leadership: Empowering and constraining beliefs. Journal of Student Affairs Research and Practice, 42, p. 111-131.

Smart, J. C., Ethington, C. A., Riggs, R. O., \& Thompson, M. D. (2002). Influences of institutional expenditure patterns on the development of students' leadership competencies. Research in Higher Education, 43, p. 115-132.

Snell, R. S., Chan, M. L., Ma, C. K., \& Chan, C. M. (2015). A road map for empowering undergraduates to practice service leadership through service-learning in teams. Journal of Management Education, 39, p. 372-399.

Spears, L. C. (1995). Reflections on leadership: How Robert K. Greenleaf's theory of servantleadership influenced today's top management thinkers. New York: Wiley.

Spence Laschinger, H. K., \& Fida, R. (2014). A time-lagged analysis of the effect of authentic leadership on workplace bullying, burnout, and occupational turnover intentions. European Journal of Work and Organizational Psychology, 23(5), p. 739-753.

Spreitzer, G. M. (2006). Leadership development lessons from positive organizational studies. Organizational Dynamics, 35, p. 305-315.

U.S. Department of Education, National Center for Education Statistics (2015). http://nces.ed.gov/fastfacts/display.asp?id=98

van Dierendonck, D., \& Nuijten, I. (2011). The servant leadership survey: Development and validation of a multidimensional measure. Journal of Business Psychology, 26, p. 249267. 
Walumbwa, F. O., Avolio, B. J., Gardner, W. L., Wernsing, T. S., \& Peterson, S. J. (2008). Authentic leadership: Development and validation of a theory-based measure. Journal of Management, 34, p. 89-125. 